\title{
Extent, perception and mitigation of damage due to high groundwater levels in the city of Dresden, Germany
}

\author{
H. Kreibich ${ }^{1}$, A. H. Thieken ${ }^{2}$, H. Grunenberg ${ }^{3}$, K. Ullrich ${ }^{4}$, and T. Sommer ${ }^{5}$ \\ ${ }^{1}$ Helmholtz Centre Potsdam German Research Centre for Geosciences (GFZ), Section Hydrology, Potsdam, Germany \\ ${ }^{2}$ alpS - Centre for Natural Hazard and Risk Management and Leopold-Franzens-University Innsbruck, Innsbruck, Austria \\ ${ }^{3}$ Leuphana University of Lueneburg, Institute for Environmental Communication, Lueneburg, Germany \\ ${ }^{4}$ City of Dresden, Environmental office, Dresden, Germany \\ ${ }^{5}$ Dresdner Grundwasserforschungszentrum e.V., Dresden, Germany
}

Received: 27 April 2009 - Revised: 13 July 2009 - Accepted: 14 July 2009 - Published: 27 July 2009

\begin{abstract}
Flood risk analysis and management plans mostly neglect groundwater flooding, i.e. high groundwater levels. However, rising groundwater may cause considerable damage to buildings and infrastructure. To improve the knowledge about groundwater flooding and support risk management, a survey was undertaken in the city of Dresden (Saxony, Germany), resulting in 605 completed interviews with private households endangered by high groundwater levels. The reported relatively low flood impact and damage of groundwater floods in comparison with mixed floods was reflected by its scarce perception: Hardly anybody thinks about the risk of groundwater flooding. The interviewees thought that public authorities and not themselves, should be mainly responsible for preparedness and emergency response. Up to now, people do not include groundwater risk in their decision processes on self protection. The implementation of precautionary measures does not differ between households with groundwater or with mixed flood experience. However, less households undertake emergency measures when expecting a groundwater flood only. The state of preparedness should be further improved via an intensified risk communication about groundwater flooding by the authorities. Conditions to reach the endangered population are good, since $70 \%$ of the interviewed people are willing to inform themselves about groundwater floods. Recommendations for an improved risk communication are given.
\end{abstract}

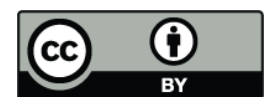

Correspondence to: $\mathrm{H}$. Kreibich (kreib@gfz-potsdam.de)

\section{Introduction}

Rising groundwater and high groundwater levels are accompanying phenomena of river floods, but are often neglected in ex-post event documentations or ex-ante risk analyses. Therefore, losses caused by high groundwater levels mostly have not been detected separately in loss assessment studies. However, rising groundwater can considerably contribute to losses due to river flooding. For instance, during the flood in August 2002 16\% of the damage on premises of the Free State of Saxony, Germany, were caused by groundwater flooding (Huber et al., 2003).

The causes for rising groundwater during flood situations are manifold: The infiltration of inundation water into the aquifer is the main process. The consequences of this process are water-filled aquifers and high groundwater levels in- and outside of the inundated area at the surface. Another process is the accumulation of groundwater from the hinterland and the superposition with the flood induced infiltrated groundwater. Particularly, long or extreme rainfall on pre-wetted soils can cause high groundwater recharge, which cannot discharge in the underground because of the infiltrated flood water. In urban areas the water can infiltrate into the underground by subterranean infrastructure, e.g. the sewerage system. Hence, the water can be distributed through the sewerage into areas outside of the inundation. Due to these complex processes it is difficult to forecast the dynamics of groundwater rise during flood situations (Bradford, 2002).

The characteristic of the rising groundwater depends on the type of the flood and on the distance to the river. Figure 1 shows two groundwater hydrographs in the city of Dresden,

Published by Copernicus Publications on behalf of the European Geosciences Union. 

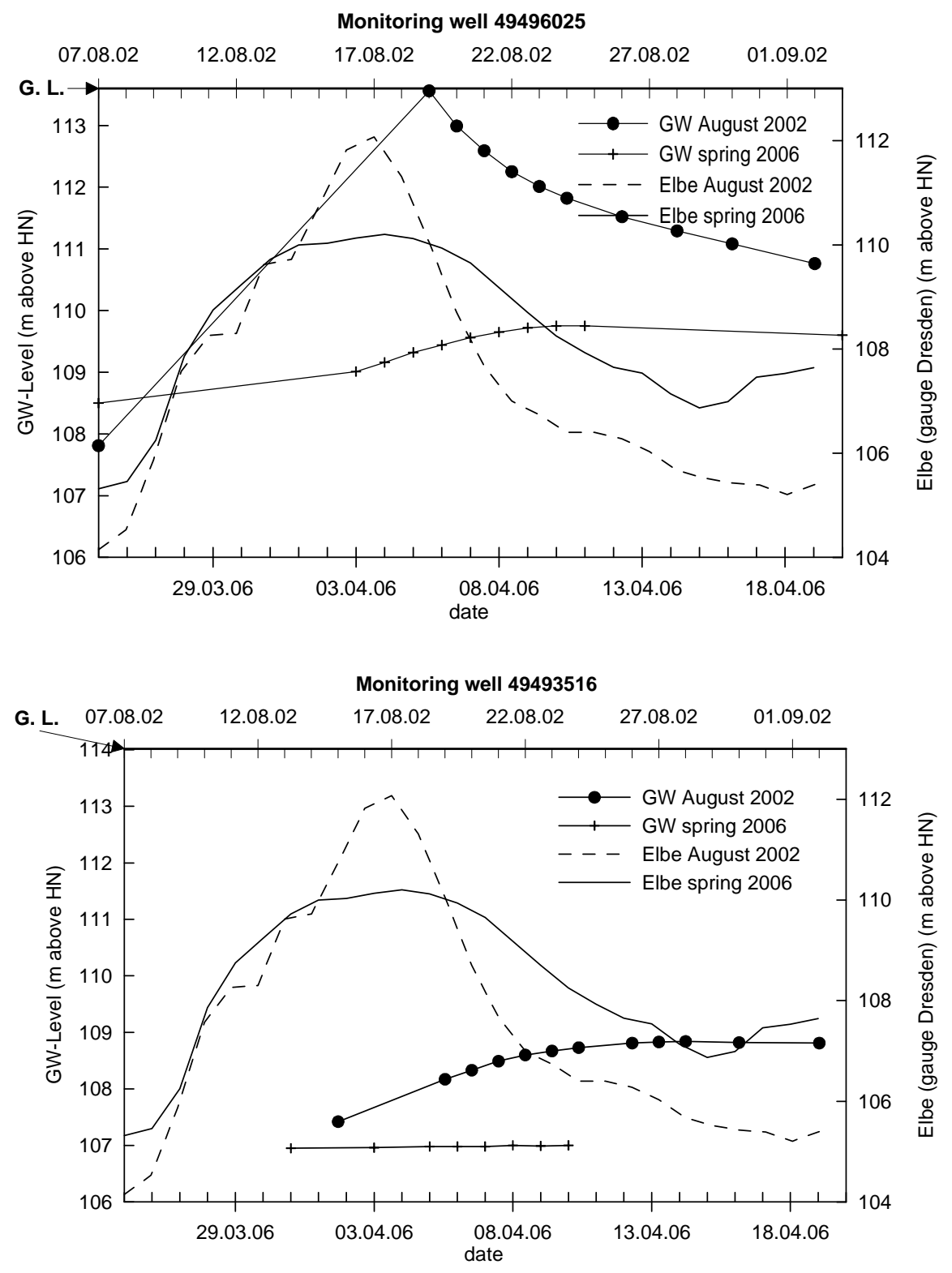

Fig. 1. Hydrographs of groundwater levels and the water level of the Elbe River in Dresden (Top: monitoring well $400 \mathrm{~m}$ away from the Elbe River; bottom: monitoring well $1.2 \mathrm{~km}$ away from the Elbe River; Data source: Saxon Regional Agency of Environment and Geology).

the capital of the Free State of Saxony in Germany, during the flood events in August 2002 and in April 2006. Coupled modelling of groundwater dynamics have shown that the steep hydrograph of the Elbe River in August 2002 and the pre-event rainfall on wet soil were the reason for the fast rising groundwater (Sommer et al., 2009). Close to the river, the groundwater reacts relatively quickly (Fig. 1, top); farther away from the river the groundwater rises slowly and can stay on a high level over a long time (Fig. 1, bottom). In spring 2006 the same monitoring wells show much lower groundwater levels than in August 2002, which was due to the significantly less severe Elbe flood and hardly any rain before the event (see Kreibich and Thieken, 2008b, for descriptions and a comparison of the two flood events).

An important parameter influencing the amount of damage due to rising groundwater is the depth to groundwater table. The lower the depth to groundwater table, the higher the risk for subsurface parts of buildings and infrastructure to be damaged. Therefore, the minimum depth to groundwater table gives a first indication of potential subsurface losses. The type of damage due to high groundwater levels differs depending on whether or not the water enters the building (Kreibich and Thieken, 2008a). Examples for damage due to water contact or capillary rise are a destruction of wooden 
floors or panelling, a damage to the heating system or damage of contents. Examples for damage due to buoyancy or lateral pressure are a demolition of the base-plate or a destruction or destabilization of the building. Additionally, the presence or absence of contamination of the groundwater and the duration of the groundwater induced inundation at the building makes a difference (Kreibich and Thieken, 2008a).

Mitigation measures can be differentiated between permanent and temporary measures (LH DD, 2005; Sommer, 2007). In areas with constantly high groundwater levels permanent measures like an appropriate construction are required. Examples are the avoidance of cellars or the waterproofed construction of cellars by tanking (e.g. waterproof concrete tanking or constructions with a waterproof skin i.e. bitumen sealing). In other areas temporary measures which are only employed in the case of a groundwater flood event are appropriate. Examples are the reduction of dangerously high groundwater levels via pumping with protection wells or the flooding of cellars to create counter pressure. Damage mitigation via temporary measures relies on a functioning warning system and good preparedness (Thieken et al., 2007; Kreibich and Thieken, 2008b).

There are no regulations about official responsibilities for subsurface groundwater flood protection. In addition, flood insurance does commonly not cover losses due to groundwater flooding in Germany (Thieken et al., 2006). Thus, undertaking precautionary measures demands self dependent action by the potentially affected population. Neither the state, the federal states (provinces), nor the communities are liable for groundwater flood damage to private property. However, people only act if they are aware of the risk of rising groundwater and if they are informed about the possibility, effectiveness and cost of private precautionary measures (Grothmann and Reusswig, 2006). Therefore, the municipal administration, e.g. the environment agency, needs good knowledge about the subsurface flood risk to identify groundwater flood endangered areas, e.g. in general development plans, to take the risk into account before and during underground construction work and to inform the people at risk about mitigation measures. For the performance of effective emergency measures in the case of an event, a groundwater-monitoring programme with a warning system is a precondition. For the municipal administration it is an important challenge to create preparedness and keep it at a high level, which may be achieved via an efficient risk communication programme. However, there is surprisingly little knowledge about the perception of groundwater flood risk so far. The nature of this risk is clearly different from other hydrological risks, leading to a number of hypotheses about its specific pattern of perception. In comparison to surface water flooding, there are essentially four features that characterise the perception of groundwater flooding:

1. No visibility: Groundwater is only rarely visible and so it is not a part of our everyday life even though it is common knowledge that groundwater is everywhere and that it somehow impacts our lives. In our perception groundwater is thus always "somewhere down there".

2. Minimal disaster potential: Groundwater does not entail enough potential risk to create a disaster and this affects its presentation in the media. As a risk it is "unexciting", that is, slow, long-lasting, at times expensive but hardly a danger to life.

3. Nescience: There is too little, even a complete lack of factual knowledge about groundwater in the general population. Little is known about the modalities and movements of groundwater. Ignorance about a risk normally leads to diffuse anxieties. However, its lack of visibility and the minimal disaster potential of groundwater flooding lead to a high degree of trivialization.

4. Intervention possibilities: Groundwater flooding can rarely be combated in joint actions, as for example river flooding is by the erection and maintenance of dikes by a threatened community. Precautionary measures against groundwater flooding are largely an individual matter.

This characteristic perception has implications for the risk communication of groundwater flooding: for instance, the basics about groundwater have to be communicated at first, so that those who might be affected can develop a certain amount of responsibility for risk mitigation.

The objective of this study is to identify measures for the improvement of the management of groundwater floods. Extent, perception and mitigation of damage triggered by high groundwater levels are compared to damage caused by mixed floods (i.e. simultaneous or consecutive groundwater and other flooding like riverine and flash floods). Recommendations for an improved risk communication with a focus on groundwater floods are given.

\section{Data and methods}

The investigation area is the city of Dresden in Germany, which was strongly affected by floods in August 2002 and spring 2006 (Engel, 2004; Belz et al., 2006; Kreibich and Thieken, 2008b). In August 2002 the water level of the Elbe River rose up to $9.40 \mathrm{~m}$ at the Dresden gauge resulting in an inundation area of $25 \mathrm{~km}^{2}$ (Fig. 2). In spring 2006 the flood reached a maximum water level of $7.49 \mathrm{~m}$ at the Dresden gauge, which caused considerably less inundation. A description of the hydrogeological situation of the city of Dresden is given in Sommer et al. (2009).

Representative telephone interviews with private households, which are endangered by high groundwater levels, were undertaken in the city of Dresden in August and September 2007. On basis of a list of streets and building 


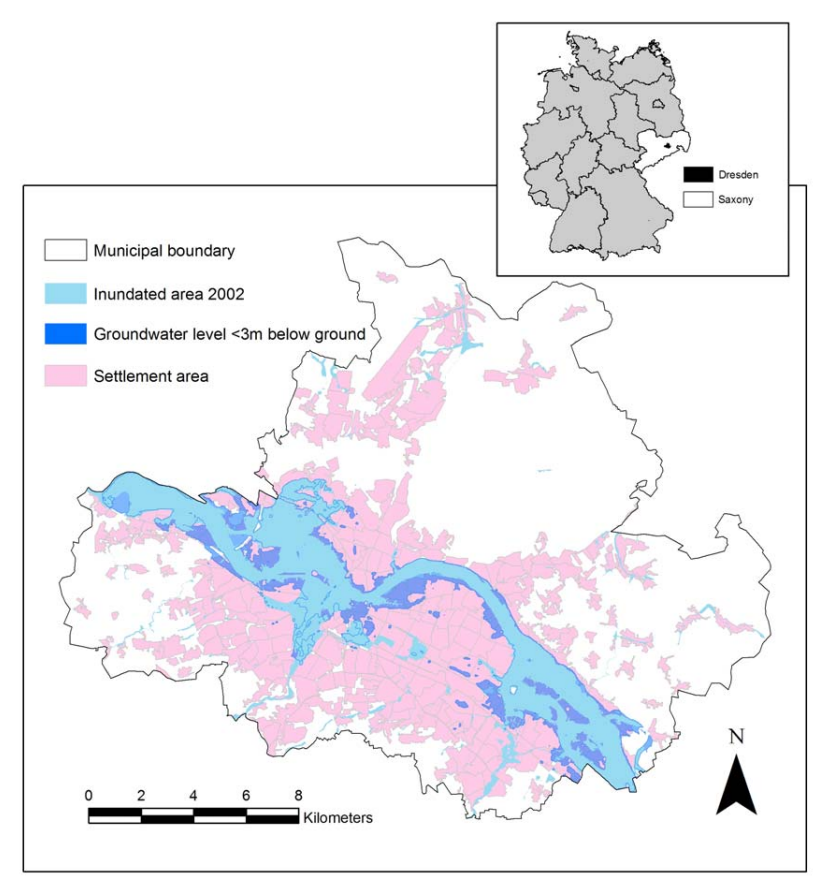

Fig. 2. Areas of high groundwater level and inundated areas during the flood in 2002 in Dresden, Saxony, Germany (Data sources: (C) Bundesamt für Kartographie und Geodäsie: municipal boundary, ATKIS ${ }^{\circledR}$ Basis DLM; City of Dresden, Environmental office: groundwater levels, inundated area in 2002).

numbers within the area of high groundwater levels, i.e. areas with a depth to groundwater table of less than three meters between August 2002 and February 2003 (Fig. 2), building specific random samples of households were generated. It was aimed at a resulting data set, which contains a majority of interviews with people who had been affected by high groundwater levels and possibly other flood types, and about $25 \%$ of interviews with people who have not yet experienced high groundwater levels, irrespective of other flood experience. Computer-aided telephone interviews were undertaken with the VOXCO software package (www.voxco.com) by the SOKO institute for social research and communication (www.soko-institut.de). The standardised questionnaire comprised around 70 questions, but not all questions were applicable in all cases. For most questions, a list of possible answers was given (with either a single answer or multiple answers possible). Questions about peoples' attitudes were evaluated on a four rank Likert-scale. An interview lasted $32 \mathrm{~min}$ on average. The questionnaire was structured into the following content oriented question-blocks: general introduction and filtering; flood impact parameters and resulting damage; building and residence characteristics; damage/risk perception; prevention, precaution and preparation; information and participation; risk management; and sociodemography.
The survey resulted in 605 completed interviews with private households, of which

- 54 had no flood experience at all,

- 97 had experienced various kinds of floods, except for groundwater floods,

- 74 had experienced groundwater flooding, and had not been affected by other flood types lately, and

- 380 had recently experienced simultaneous or consecutive groundwater and other flooding during one event (mixed flood).

The vast majority of households with groundwater flood experience $(n=454)$ stated that their most recent experience was in $2002(n=402,89 \%)$, followed by the floods in $2006(n=13$, $3 \%)$ and $2007(n=13,3 \%)$. Ten households were affected between 1967 and 2001, and 14 between 2003 and 2005 for the last time.

To better handle the information of the data set, answers concerning one particular topic were aggregated into one indicator variable. This was done for contamination, precautionary measures and emergency measures. The contamination indicator ranges from zero (=no contamination) to two (=multiple contamination including oil) according to Büchele et al. (2006). The indicators for precautionary and emergency measures simply consist of the number of performed measures.

Significant differences between two independent groups of data, e.g. groundwater and mixed flood cases, were tested by the Mann-Whitney-U-Test, significant differences between the four independent, differently experienced groups of people were tested by the Kruskal-Wallis-H test (Norusis, 2002). Principal component analysis (PCA) with varimax rotation was applied in order to investigate the correlation structure of the precaution influencing variables. A significance level of $p<0.05$ was applied. Statistical analyses were undertaken with the software SPSS for Windows, Version 11.5.1.

\section{Results and discussion}

\subsection{Flood impact and resulting damage}

To further characterise groundwater floods and to analyse whether characteristics of groundwater floods significantly differ from other floods, flood impact variables (i.e. water level, flood duration and contamination) of two data subsets were compared (Fig. 3). The two subsets contain households, which were only affected by groundwater floods and those that were affected by various flood types including groundwater, respectively. Significant differences exist for the water level above the cellar floor and the contamination of the flood water. While groundwater flooding causes an average inundation height of $68 \mathrm{~cm}$ above the cellar floor this value 


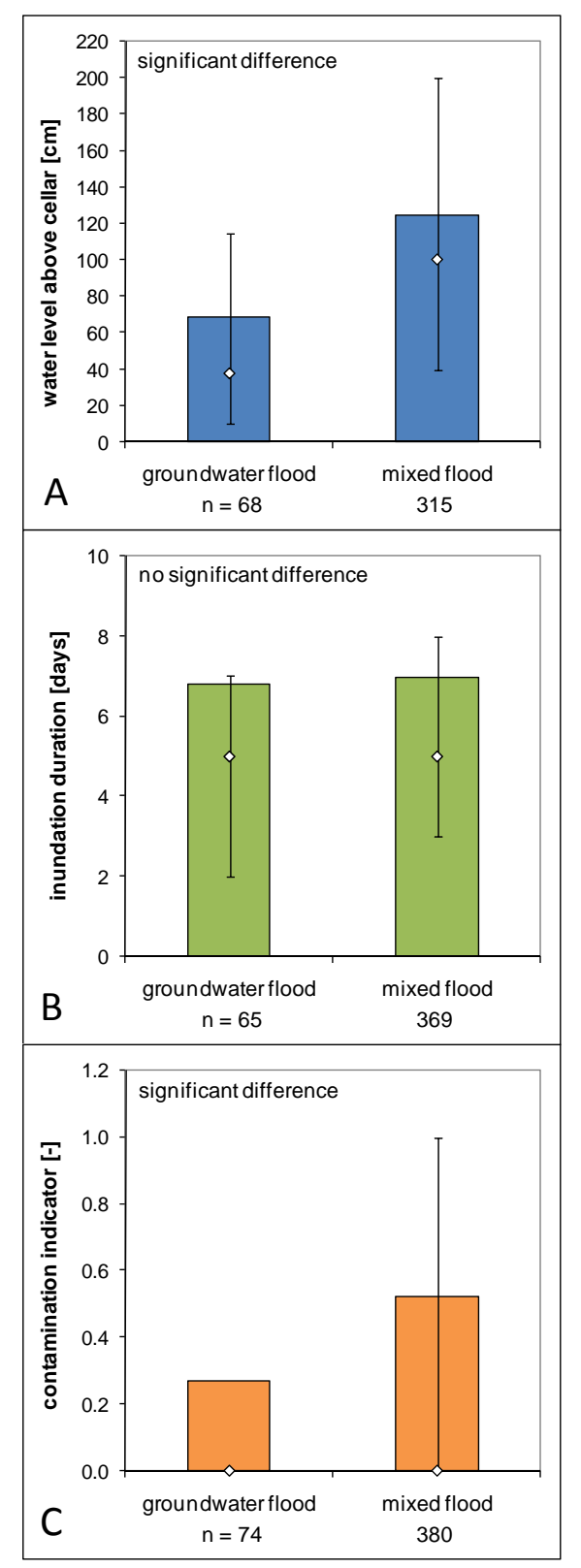

Fig. 3. Flood impact parameters ((A) water level; (B) duration; (C) contamination) for groundwater and mixed flood cases (bars $=$ means; dots $=$ medians and $25-75 \%$ percentiles).

amounts to $124 \mathrm{~cm}$ for mixed floods. The mean value of the contamination indicator is 0.27 for groundwater flooding and 0.52 for mixed floods. That means that the mean and median values for theses two variables are approximately twice as high in cases affected by mixed floods in comparison to cases that were only affected by groundwater floods (Fig. 3). Surprisingly, no significant difference was observed for flood duration (Fig. 3). Altogether, the flood impact is lower for groundwater floods in comparison to a mixed flood situation.

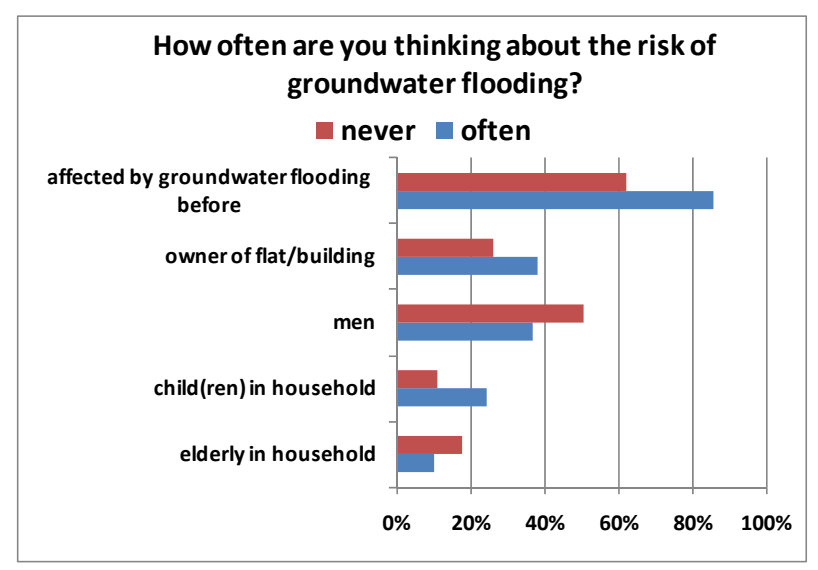

Fig. 4. Percentage of specific people in the groups who never $(n=61)$ or often $(n=133)$ think about the risk of groundwater flooding.

The lower flood impact is reflected by the information about structural damage and financial losses (see Table 1). Except for the item "collapse of building parts" the percentage of cases with a specific structural damage is lower in the data subset that comprises only groundwater flooding. However, the differences are only significant for the damage type "moisture penetration of building walls". This suggests that in a great number of groundwater flood cases only the cellar floor was affected.

Also the financial losses given as repair or replacement costs differ significantly between groundwater flooding and mixed floods (Table 1). Again, in the case of groundwater flooding significantly less repair costs occur: The average building loss amounts to 8516Euro in contrast to 36652 Euro for mixed flood cases and the average content loss is 1000 Euro for groundwater flooding in contrast to 7571 Euro for mixed floods. More than 50\% of the households affected by groundwater flooding only, had no monetary building or content losses (Table 1). That means that the losses for mixed flooding are around four to seven times higher than losses due to rising groundwater although the flood impact variables only differ by a factor of two (see Fig. 3 and Table 1).

\subsection{Risk perception}

The relatively low flood impact and damage of groundwater floods is reflected by its scarce perception. $66 \%$ of the interviewed people only sometimes, rarely or never think about the risk of groundwater flooding. Particularly many people who were not affected by groundwater flooding before have never been thinking about it (Fig. 4 and Table 2). Additionally, more tenants, men, elderly and people without children have never been thinking about groundwater flooding (Fig. 4). 
Table 1. Damage parameters in the two sub-datasets: I) households affected by groundwater flood only II) households affected by mixed floods (* significant difference between the two subgroups).

\begin{tabular}{lrr}
\hline & $\begin{array}{r}\text { I) Groundwater } \\
\text { flood cases }\end{array}$ & $\begin{array}{r}\text { II) Mixed flood } \\
\text { cases }\end{array}$ \\
\hline \% of cases with a collapse of building parts & 4 & 3 \\
\% of cases with large cracks, subsidence or deformation of the building & 10 & 16 \\
$\%$ of cases with small cracks in the building & 12 & 23 \\
\% of cases with moisture penetration of building walls & $64^{*}$ & $83^{*}$ \\
Mean (median) building loss [€] & $8,516(0)^{*}$ & $36,652(5000)^{*}$ \\
Mean (median) contents loss [€] & $1,000(0)^{*}$ & $7,571(500)^{*}$ \\
\hline
\end{tabular}

Table 2. Selected statements, e.g. attitudes which are significantly different in four subgroups: 1) people with no flood experience at all $(n=54)$; 2) people which experienced various kinds of floods, except groundwater floods $(n=97)$; 3) people which experienced groundwater flooding, and had not been affected by other flood types lately $(n=74)$; and 4 ) people which recently experienced simultaneous groundwater and other flooding $(n=380)$.

\begin{tabular}{lcccc}
\hline Statements & group 1 & group 2 & group 3 & group 4 \\
\hline $\begin{array}{l}\text { Percentage of people who } \\
\text { never think about the risk } \\
\text { of groundwater flooding }\end{array}$ & $38 \%$ & $29 \%$ & $14 \%$ & $11 \%$ \\
\hline $\begin{array}{l}\text { Percentage of people who } \\
\text { are "very much" interested } \\
\text { in riverine and } \\
\text { groundwater flooding }\end{array}$ & $33 \%$ & $45 \%$ & $31 \%$ & $50 \%$ \\
\hline $\begin{array}{l}\text { Percentage of people who } \\
\text { consider financial losses to } \\
\text { be "very bad" }\end{array}$ & $44 \%$ & $55 \%$ & $28 \%$ & $38 \%$ \\
\hline $\begin{array}{l}\text { Percentage of people who } \\
\text { consider repair and } \\
\text { replacement activities to } \\
\text { be "very bad" }\end{array}$ & $22 \%$ & $31 \%$ & $20 \%$ & $29 \%$ \\
\hline $\begin{array}{l}\text { Percentage of people who } \\
\text { are willing to inform } \\
\text { themselves about } \\
\text { groundwater floods }\end{array}$ & $59 \%$ & $56 \%$ & $69 \%$ & $76 \%$ \\
\hline
\end{tabular}

On the other hand, there is a general interest in flood issues: $45 \%$ of the interviewed people with (mixed) flood experience stated that they are "very much" interested in the topic of riverine and groundwater flooding, whereas this is true for only one third of the people with no flood experience or with groundwater flood experience only (Table 2). This is in accordance with the finding that groundwater flooding is considered to be much less important than riverine flooding (Heinrichs and Grunenberg, 2009).

The statement "groundwater flooding is normal in Dresden, one is forced to accept the damage also in the future" is agreed on by $52 \%$ of the interviewed people. Apparently, the willingness to resist is not very common in the population.
Although public authorities can do little to protect the population and mitigate damage from groundwater flooding, they are nevertheless given the main responsibility for precaution and emergency measures (Table 3). Additionally, $46 \%$ of the interviewed people agree totally that affected people should organise themselves and help each other in the case of a groundwater flood event. Individual responsibility is least popular for precaution as well as for emergency response (Table 3). This shows a clear discrepancy between the objective situation and the perception of the risk situation.

In summary, hardly anybody cares about the risk of groundwater flooding and not many judge themselves responsible for mitigation measures. 
Table 3. Percentages of answers to the question "Who should be responsible for the prevention against groundwater flooding? Please state how much you agree on the following statements."

\begin{tabular}{|c|c|c|c|c|c|}
\hline Statements & $\begin{array}{c}\text { total } \\
\text { agreement }\end{array}$ & $\begin{array}{c}\text { partial } \\
\text { agreement }\end{array}$ & $\begin{array}{c}\text { partial } \\
\text { disagreement }\end{array}$ & $\begin{array}{c}\text { total } \\
\text { disagreement }\end{array}$ & $\begin{array}{l}\text { don't } \\
\text { know }\end{array}$ \\
\hline $\begin{array}{l}\text { Public authorities are } \\
\text { responsible for precaution } \\
\text { against groundwater } \\
\text { flooding. }\end{array}$ & 62.5 & 23.1 & 7.9 & 3.6 & 2.8 \\
\hline $\begin{array}{l}\text { Everybody is individually } \\
\text { responsible for precaution } \\
\text { against groundwater } \\
\text { flooding. }\end{array}$ & 18.2 & 23.8 & 21.7 & 30.6 & 5.8 \\
\hline $\begin{array}{l}\text { The endangered people } \\
\text { are jointly responsible for } \\
\text { precaution against } \\
\text { groundwater flooding. }\end{array}$ & 27.4 & 31.9 & 17.2 & 17.2 & 6.3 \\
\hline $\begin{array}{l}\text { Public authorities are } \\
\text { responsible for emergency } \\
\text { control in the case of a } \\
\text { groundwater flood event. }\end{array}$ & 65.6 & 22.1 & 5.1 & 3.6 & 3.5 \\
\hline $\begin{array}{l}\text { Everybody is responsible } \\
\text { for him-/herself in the } \\
\text { case of a groundwater } \\
\text { flood event. }\end{array}$ & 12.4 & 18.2 & 31.2 & 33.9 & 4.3 \\
\hline $\begin{array}{l}\text { Affected people should } \\
\text { organise themselves and } \\
\text { help each other in the case } \\
\text { of a groundwater flood } \\
\text { event. }\end{array}$ & 46.3 & 33.2 & 11.2 & 7.1 & 2.1 \\
\hline
\end{tabular}

\subsection{State of private precaution}

The most popular precautionary measures which had been undertaken before as well as after the flood event by many households irrespective of the type of their flood experience were the adaptation of the cellar use, the storage of hazardous substances upstairs as well as the adaptation of the interior fitting in the cellar (Fig. 5). With only about 15\%, surprisingly few households had collected information about flood precaution before the flood. However, this was the most popular measure undertaken after the flood.

There is basically no difference in the preparedness of households with groundwater or mixed flood experience (Fig. 5). The only exceptions relate to the measures of an adapted interior fitting in the cellar and constructural precaution. More households had adapted their interior fitting in the cellar before they experienced a groundwater flood (42\%) in contrast to the ones which experienced a mixed flood (29\%). Consequently, less households with only groundwater flood experience stated that it is not intended or not possible to undertake this measure (23\%) in contrast to the households with mixed flood experience (36\%). More households which had experienced a mixed flood undertook constructural improvements (retrofitting) after the flood (17\%) in contrast to the ones which had experienced a groundwater flood only $(8 \%)$.

The most popular emergency measures undertaken by more than $35 \%$ of the households irrespective of the experienced flood type were neighbourly help, putting moveable contents from the cellar to higher stories, installation of water pumps as well as the safeguarding of documents and valuables (Fig. 6). Only about $10 \%$ of the households did not undertake any emergency measures.

Generally, similar emergency measures were undertaken before or during a groundwater or mixed flood (Fig. 6). However, significantly less households which experienced only a groundwater flood safeguarded their documents and valuables $(35 \%)$, switched off gas or electricity (31\%), installed water pumps (43\%) and created counter pressure e.g. via an artificial flooding of the cellar to avoid structural damage via buoyancy $(0 \%)$, in contrast to households which experienced a mixed flood. 

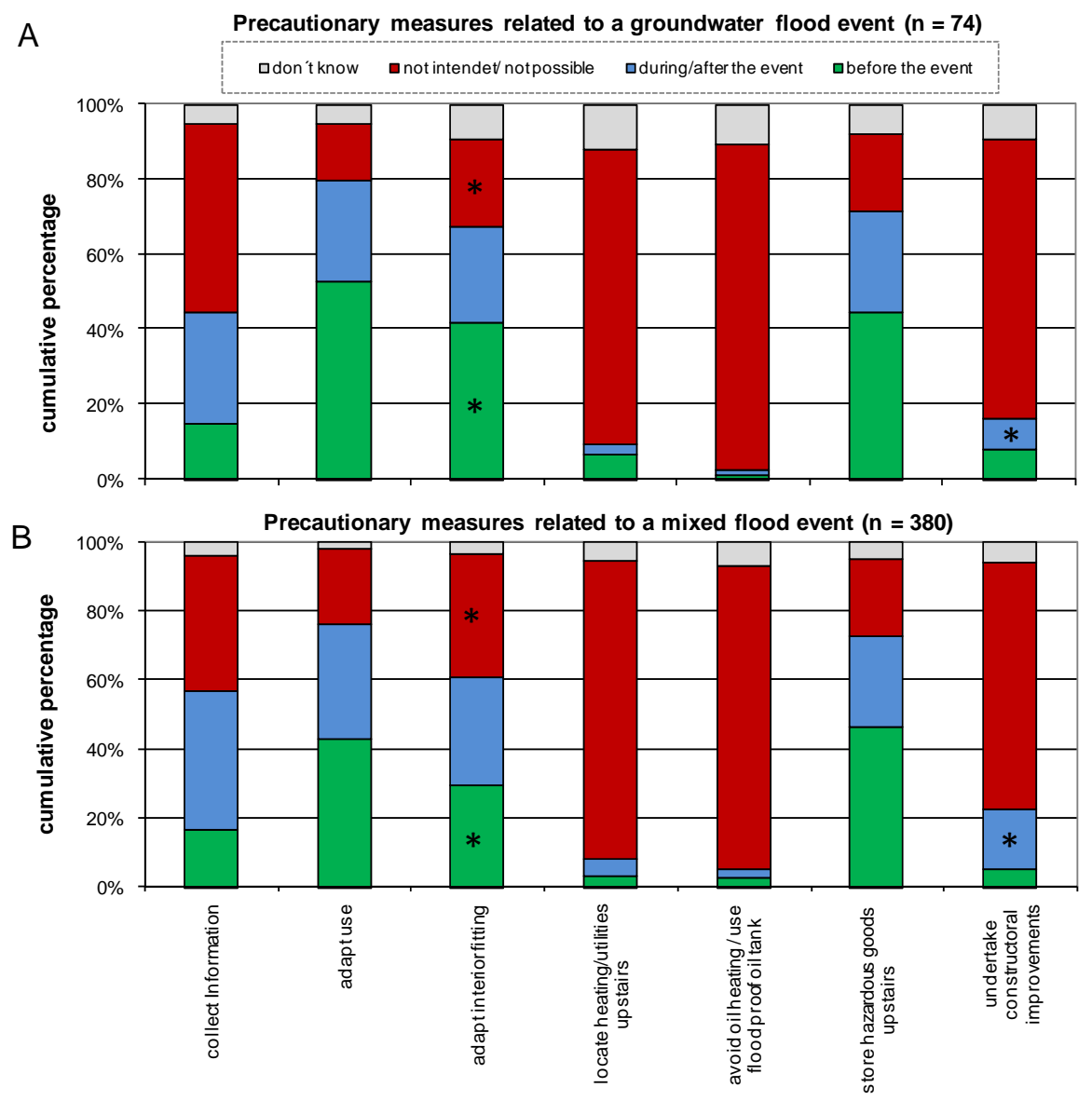

Fig. 5. Proportion of households, which undertook specific measures of precaution before, or during/after their last experienced groundwater flood event (A) or mixed flood event (B), or which do not intend/for which it is not possible to undertake the measure (measures marked with a * show a significant difference between groundwater and mixed flood cases).

To better understand the interaction between the variables that might influence the motivation to undertake precautionary and/or emergency measures a PCA was performed (Table 4). Six significant principal components were extracted, since there was a sharp bend in the scree plot at six components, where the eigenvalues clearly level off to the right of the plot. They account for $41 \%$ of the total variance. To assess which components strongly influence the motivation to undertake precautionary and/or emergency measures, the precautionary and emergency measures indicators were included in the PCA.

The first and second components are marked by high loadings of items that describe the perception of the interviewed households about the responsibility for precaution and emergency control (Table 4). The third component is particularly marked by high loadings of items characterising concerns about flooding, but also flood experience items and the item about the "appraisal of the probability to be affected by inundation due to an overloaded sewerage system in the future" have rather high loadings. Number of young persons and children in the household (as well as the ownership structure) are the dominating items in the fourth component. Items about the appraisal of future flood probability dominate the fifth component. The sixth component is marked by high loadings of two socio-economic items (perception of social rank of interviewee and ownership structure) additionally two flood experience items have rather high loadings (Table 4). The loadings of the two socio-economic items suggest that more tenants attribute themselves with a low social rank in comparison with homeowners.

Table 4 shows that the precautionary indicator has its highest loadings at the young persons/children component (4) and the component (6) that describes the perception of social rank (ownership structure and flood experience). The finding that the more young persons and children are in a household, the more precautionary measures were undertaken corresponds with Brenniman (1994), who found out that one-person households spent the least amount of money on flood protection measures, while households with six or more people spent the most. Additionally, it was shown 


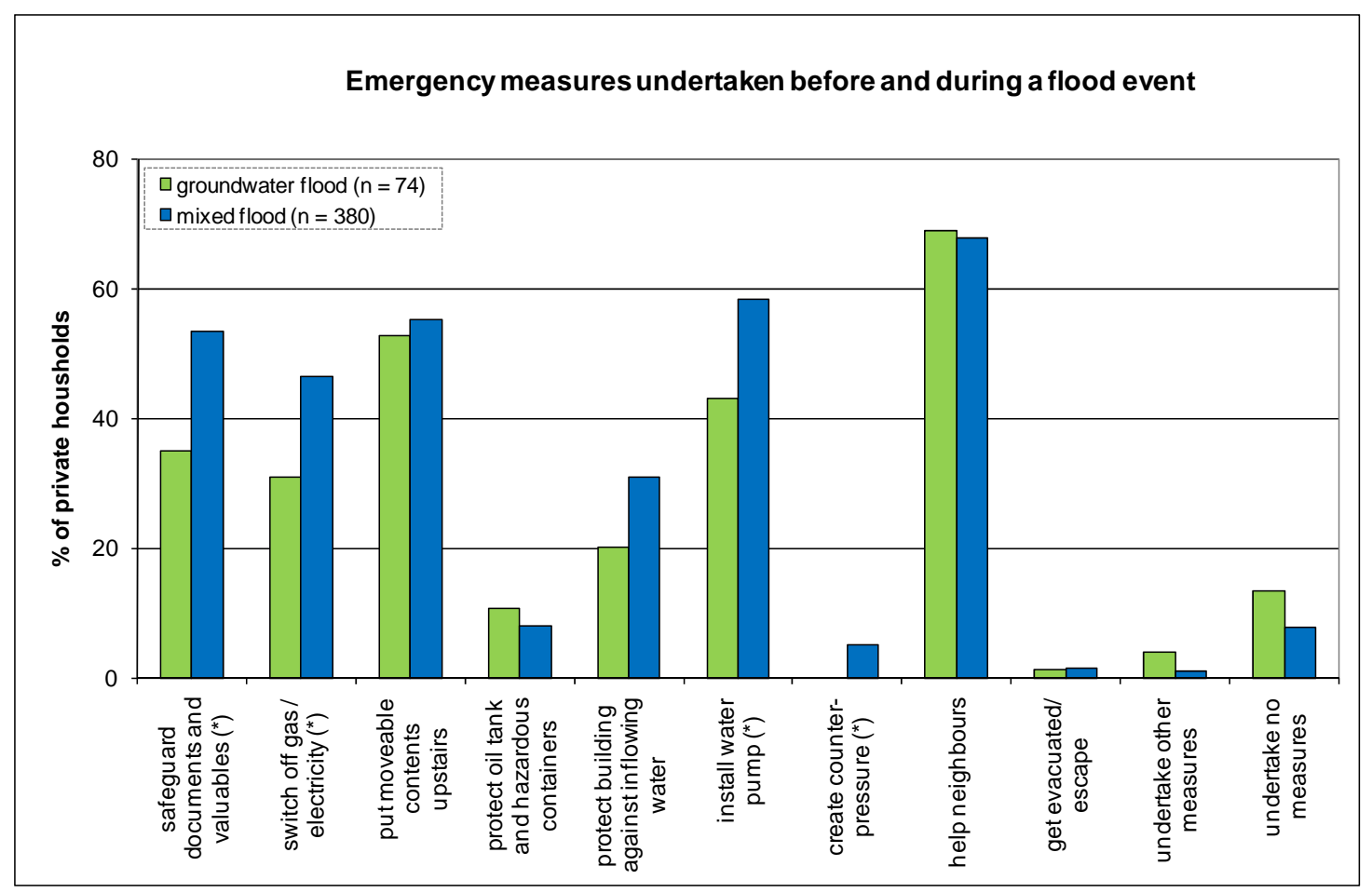

Fig. 6. Emergency measures performed by households (multiple answers possible, measures marked with a $*$ show a significant difference between groundwater and mixed flooding).

before, that homeowners are more likely to undertake precautionary measures in comparison with tenants (Kreibich et al., 2005; Grothmann and Reusswig, 2006; Thieken et al., 2007). Flood experience is a significant factor for the motivation to undertake precautionary measures (Kreibich et al., 2005; Grothmann and Reusswig, 2006; Siegrist and Gutscher, 2006, 2008; Thieken et al., 2007). As the precautionary indicator, the emergency measures indicator has its highest loadings at components four and six.

In summary, the implementation of precautionary measures does not differ between households with groundwater or with mixed flood experience. However, lesser households undertake emergency measures when expecting a groundwater flood only. Household characteristics like young persons/children in household or ownership structure influence the thinking about groundwater flooding (Fig. 4) as well as the implementation of mitigation measures (Table 4).

\subsection{Risk communication}

Many people (57\%) expect that public authorities provide general information about groundwater flooding. However, only $40 \%$ of the interviewed people judge the information presented by the authorities in Dresden to be extensive and $61 \%$ wish that the authorities offer more information. $70 \%$ of the interviewed people are willing to inform themselves about groundwater floods. Particularly people who were affected by a groundwater flood before are willing to do so (Table 2). Therefore, risk communication about groundwater flooding should be improved by the authorities, and conditions to reach the endangered population are good. Means of information should be preferably radio, television and newspapers (Table 5). In addition, the internet seems to be a relatively good way to reach the population, whereas flyer, public involvement procedures or road shows and seminars are unfavorable.

\section{Conclusions}

Losses due to groundwater floods are significantly lower than the ones due to mixed floods. This fact, overlaid with a low perception of groundwater flooding compared to surface flooding leads to a reduced effort to mitigate the risk of groundwater flooding, i.e. not many judge themselves responsible for precautionary and emergency measures. Up to now, people do not include groundwater risk in their decision processes on self protection. These results are clearly in contrast to the perception and mitigation of (surface) river flooding. Therefore, risk communication about groundwater flooding should be intensified by the authorities. Conditions to reach the endangered population are good, since there is a general high interest in flood issues and $70 \%$ of the 
Table 4. Component loadings for variables that might influence the motivation to undertake precautionary and/or emergency measures (principal component analysis with varimax rotation; total variance explained is $41 \%$, number of valid cases is 116 ).

\begin{tabular}{|c|c|c|c|c|c|c|c|}
\hline \multirow[b]{2}{*}{ Topics } & \multirow[b]{2}{*}{ Items } & \multicolumn{6}{|c|}{ Components* } \\
\hline & & 1 & 2 & 3 & 4 & 5 & 6 \\
\hline \multirow{5}{*}{ Flood experiences } & Latest event was a groundwater or mixed flood. & 0.06 & -0.03 & 0.41 & -0.04 & 0.23 & 0.03 \\
\hline & Absolute monetary building loss caused by latest event. & 0.02 & -0.03 & 0.58 & 0.17 & -0.05 & 0.00 \\
\hline & Absolute monetary contents loss caused by latest event. & 0.00 & -0.02 & 0.48 & 0.01 & -0.04 & -0.21 \\
\hline & $\begin{array}{l}\text { Perception of quality of information about groundwater flood during } \\
\text { latest event. }\end{array}$ & 0.01 & -0.08 & 0.03 & -0.03 & -0.09 & 0.47 \\
\hline & Number of flood experiences before the latest event. & 0.01 & -0.07 & -0.01 & -0.04 & 0.01 & -0.42 \\
\hline \multirow{5}{*}{ Appraisal of future flood probability } & $\begin{array}{l}\text { Appraisal of the probability to be affected by groundwater flooding in } \\
\text { the future. }\end{array}$ & -0.01 & -0.07 & -0.03 & -0.12 & 0.58 & 0.15 \\
\hline & $\begin{array}{l}\text { Appraisal of the probability to be affected by riverine flooding of the } \\
\text { Elbe River in the future. }\end{array}$ & -0.04 & 0.12 & 0.05 & 0.04 & 0.89 & 0.00 \\
\hline & $\begin{array}{l}\text { Appraisal of the probability to be affected by flash floods of the Elbe } \\
\text { tributaries in the future. }\end{array}$ & -0.03 & -0.03 & -0.01 & 0.06 & 0.56 & -0.17 \\
\hline & $\begin{array}{l}\text { Appraisal of the probability to be affected by inundation due to an } \\
\text { overloaded sewerage system in the future. }\end{array}$ & 0.01 & 0.17 & 0.44 & -0.10 & -0.10 & 0.33 \\
\hline & $\begin{array}{l}\text { Appraisal of the probability to be affected by inundation due to a dyke } \\
\text { beach in the future. }\end{array}$ & -0.08 & -0.10 & 0.02 & -0.19 & -0.06 & -0.11 \\
\hline \multirow{2}{*}{ Concerns about flooding } & General interest in flooding. & -0.05 & 0.22 & -0.68 & 0.04 & 0.01 & 0.01 \\
\hline & Number of times worried about groundwater flooding. & 0.20 & -0.03 & -0.52 & 0.20 & 0.17 & 0.21 \\
\hline \multirow{7}{*}{ Perception about responsibility } & $\begin{array}{l}\text { Perception that public services are responsible for groundwater flood } \\
\text { precaution. }\end{array}$ & 0.00 & 0.67 & 0.00 & 0.00 & -0.14 & 0.15 \\
\hline & $\begin{array}{l}\text { Perception that all endangered people should jointly undertake } \\
\text { groundwater flood precaution. }\end{array}$ & -0.06 & 0.53 & -0.09 & 0.07 & 0.09 & 0.02 \\
\hline & $\begin{array}{l}\text { Perception that groundwater flood precaution is everyone's own re- } \\
\text { sponsibility. }\end{array}$ & 0.02 & 0.66 & -0.07 & -0.20 & -0.11 & 0.00 \\
\hline & $\begin{array}{l}\text { Perception that in the case of a groundwater flood public services are } \\
\text { responsible for emergency control. }\end{array}$ & 0.96 & -0.03 & 0.03 & 0.03 & -0.04 & -0.01 \\
\hline & $\begin{array}{l}\text { Perception that in the case of a groundwater flood the affected people } \\
\text { need to help each other and organise themselves. }\end{array}$ & -0.17 & -0.03 & -0.22 & 0.22 & -0.05 & 0.39 \\
\hline & $\begin{array}{l}\text { Perception that in the case of a groundwater flood emergency mea- } \\
\text { sures are everyone's own responsibility. }\end{array}$ & -0.06 & 0.60 & 0.06 & 0.08 & 0.19 & -0.02 \\
\hline & $\begin{array}{l}\text { Expectance that public services undertake protection measures against } \\
\text { groundwater flooding. }\end{array}$ & 0.96 & -0.04 & 0.03 & 0.00 & -0.04 & -0.02 \\
\hline \multirow{9}{*}{ Socio-economic structure of household } & Ownership structure: tenant or owner of flat/building. & 0.16 & -0.03 & 0.28 & 0.41 & 0.15 & -0.41 \\
\hline & Sex of interviewee. & 0.20 & 0.24 & 0.00 & 0.14 & 0.17 & 0.29 \\
\hline & Year of birth of interviewee. & -0.16 & -0.39 & -0.07 & 0.35 & -0.16 & -0.20 \\
\hline & Number of people in household. & 0.00 & 0.00 & -0.08 & 0.30 & 0.03 & 0.01 \\
\hline & Number of young persons below 18 years old in household. & -0.05 & -0.13 & 0.00 & 0.74 & -0.14 & -0.04 \\
\hline & Number of children below 6 years old in household. & -0.04 & -0.05 & 0.09 & 0.69 & -0.12 & 0.08 \\
\hline & Number of persons above 75 years old in household. & 0.07 & 0.45 & -0.31 & -0.12 & -0.12 & -0.12 \\
\hline & Highest graduation of interviewee. & -0.31 & -0.08 & 0.22 & 0.21 & -0.38 & 0.04 \\
\hline & Perception of social rank of interviewee. & 0.05 & 0.05 & -0.01 & 0.04 & 0.26 & 0.55 \\
\hline Precautionary measures & $\begin{array}{l}\text { Precautionary indicator (number of precautionary measures under- } \\
\text { taken before and after the latest event). }\end{array}$ & 0.11 & 0.17 & 0.05 & 0.38 & 0.22 & -0.34 \\
\hline Emergency measures & $\begin{array}{l}\text { Emergency measures indicator (number of emergency measures un- } \\
\text { dertaken before and during the latest event). }\end{array}$ & -0.06 & -0.14 & 0.23 & 0.42 & 0.04 & -0.58 \\
\hline
\end{tabular}

\footnotetext{
* bold values indicate variables with absolute loadings $>0.4$.
} 
Table 5. Percentages of answers to the question "How important for you are the following means of information to gain knowledge about groundwater flooding before an event?"

\begin{tabular}{lrrrrr}
\hline & $\begin{array}{r}\text { very } \\
\text { important }\end{array}$ & $\begin{array}{r}\text { rather } \\
\text { important }\end{array}$ & $\begin{array}{r}\text { rather } \\
\text { unimportant }\end{array}$ & $\begin{array}{r}\text { totally } \\
\text { unimportant }\end{array}$ & $\begin{array}{r}\text { don't } \\
\text { know }\end{array}$ \\
\hline Radio & 70.9 & 23.5 & 3.8 & 1.3 & 0.5 \\
Television & 59.8 & 29.9 & 6.6 & 2.8 & 0.8 \\
Newspapers, magazines & 49.3 & 37.7 & 7.1 & 5.1 & 0.8 \\
Information by authorities & 46.9 & 36.9 & 9.1 & 5.5 & 1.7 \\
Internet & 34.7 & 23.6 & 12.9 & 20.8 & 7.9 \\
Personal communication & 32.2 & 30.7 & 23.3 & 12.1 & 1.7 \\
Flyer & 25.8 & 35.2 & 21.8 & 15.7 & 1.5 \\
Public involvement procedures & 19.3 & 32.7 & 21.8 & 14.4 & 11.7 \\
Professional journal & 12.7 & 20.5 & 37.4 & 27.6 & 1.8 \\
Road shows, seminars & 11.6 & 28.3 & 34.4 & 23.6 & 2.1 \\
Books & 8.8 & 19.0 & 35.9 & 33.9 & 2.5 \\
\hline
\end{tabular}

interviewed people are willing to inform themselves about groundwater floods.

The following recommendations for an improved risk communication with a focus on groundwater floods can be given on basis of the undertaken investigations: Since there is almost no awareness of the subject, any efforts to develop an understanding of risk among those endangered by groundwater flooding are welcome. However, communication should primarily concentrate on the necessity of individual preparedness. To motivate people to undertake mitigation measures, it is not advantageous to only point out the economic benefits arising from prevention measures against groundwater flooding, but also to focus on the ideal losses, e.g. mementos, that might occur. Traditional media, especially radio, television and newspapers, should be used to awaken the population's interest in taking action to protect themselves and to let them know where they can find more detailed information, for example in the internet. Communication campaigns should focus on particular social-groups, like tenants or singles. Additionally, people who have not been affected by groundwater flooding recently should be particularly addressed.

Acknowledgements. Survey and data analysis were undertaken within the project MULTISURE - Development of Multisequential Mitigation Strategies for Urban Areas with Risk of Groundwater Flood. We thank the German Federal Ministry for Education and Research (BMBF) (no. 0330755) and the German Research Centre for Geosciences (GFZ) for financial support.

Edited by: A. Schumann

Reviewed by: two anonymous referees

\section{References}

Belz, J. U., Burek, P., Matthäus, H., Rudolf, B., Vollmer, S., and Wiechmann, W.: Das Hochwasser der Elbe im Frühjahr 2006 (The Elbe Flood at Spring 2006), Report, Federal Agency of Hydrology, Koblenz, Germany, Report No. BFG-1514, 2006.

Bradford, R. B.: Volume-duration growth curves for flood estimation in permeable catchments, Hydrol. Earth Syst. Sci., 6, 939947, 2002, http://www.hydrol-earth-syst-sci.net/6/939/2002/.

Brenniman, G. R.: Flood damage in the upper des Plaines river basin of northeastern Illinois, The Environmental Professional, 16, 73-78, 1994.

Büchele, B., Kreibich, H., Kron, A., Thieken, A., Ihringer, J., Oberle, P., Merz, B., and Nestmann, F.: Flood-risk mapping: contributions towards an enhanced assessment of extreme events and associated risks, Nat. Hazards Earth Syst. Sci., 6, 485-503, 2006 , http://www.nat-hazards-earth-syst-sci.net/6/485/2006/.

Engel, H.: The flood event 2002 in the Elbe river basin: causes of the flood, its course, statistical assessment and flood damages, Houille Blanche, 2004(6), 33-36, 2004.

Grothmann, T. and Reusswig, F.: People at risk of flooding: Why some residents take precautionary action while others do not, Nat. Hazards, 38(1-2), 101-120, 2006.

Heinrichs, H. and Grunenberg, H.: Klimate Change and the Society, The Perspective of Adaption Communication, VS-Verlag, Wiesbaden, 2009.

Huber, G., Hiller, G., and Braune, A.: Concepts of Flood Control Measures for the Buildings of Free State Saxony in the Historical Town of Dresden, in: Flood-After-treatment Groundwater, Proceedings of the Status Workshop 8 October 2003, Dresden, 57-61, 2003.

Kreibich, H., Thieken, A. H., Petrow, Th., Müller, M., and Merz, B.: Flood loss reduction of private households due to building precautionary measures - lessons learned from the Elbe flood in August 2002, Nat. Hazards Earth Syst. Sci., 5, 117-126, 2005, http://www.nat-hazards-earth-syst-sci.net/5/117/2005/.

Kreibich, H. and Thieken, A. H.: Assessment of damage caused by 
high groundwater inundation, Water Resour. Res., 44, W09409, doi:10.1029/2007WR006621, 2008a.

Kreibich, H. and Thieken, A. H.: Coping with floods in the city of Dresden, Germany, Nat. Hazards, doi:10.1007/s11069-0079200-8, 2008b.

LH DD (City of Dresden): Auswirkungen des Hochwassers 2002 auf das Grundwasser, final project report, Dresden, 2005.

Norusis, M. J.: SPSS 11.0 guide to data analysis, Prentice Hall, Upper Saddle River, USA, 2002.

Siegrist, M. and Gutscher, H.: Flooding Risks: A Comparison of Lay People's Perceptions and Expert's Assessments in Switzerland, Risk Anal., 26(4), 971-979, 2006.

Siegrist, M. and Gutscher, H.: Natural hazards and Motivation for Mitigation Behavior: People Cannot Predict the Affect Evoked by a Severe Flood, Risk Anal., 28(3), 771-778, 2008.
Sommer, T., Karpf, C., Ettrich, N., Haase, D., Weichel, T., Peetz, J.-V., Steckel, B., Eulitz, K., and Ullrich, K.: Coupled Modelling of Subsurface Water Flux for an Integrated Flood Risk Management, Nat. Hazards Earth Syst. Sci., submitted, 2009.

Sommer, T.: Groundwater Management - a Part of Flood Risk Management, in: Groundwater for Emergency situations, edited by: Vrba, J. and Salamet, A. R., IHP Groundwater-Series, 15, 35-44, 2007. (http://unesdoc.unesco.org/images/0015/001559/155960e. pdf, last access: 09.03.2009)

Thieken, A. H., Petrow, T., Kreibich, H., and Merz, B.: Insurability and mitigation of flood losses in private households in Germany, Risk Anal., 26(2), 383-395, 2006.

Thieken, A. H., Kreibich, H., Müller, M., and Merz, B.: Coping with floods: A survey among private households affected by the August 2002 flood in Germany, Hydrolog. Sci. J., 52(5), 10161037, 2007. 